\title{
Reconsidering the Summer Residence: The City-Text, Historical Commemoration and Banal Settler Geography
}

\author{
Bryan Smith \\ Faculty of Education \\ York University \\ bryansmi@,edu.yorku.ca
}

\begin{abstract}
It was not much larger than a canoe [the boat of a surveyor], but we ventured into it, and after rowing a mile we came within sight of what is named, in the map, the highlands of Toronto. The shore is extremely bold, and has the appearance of chalk cliffs, but I believe they are only white sand. They appeared so well that we talked of building a summer residence there and calling it Scarborough. (Robertson, 1911, p. 180)
\end{abstract}

In 1793, Elizabeth Simcoe, along with her husband (John Graves Simcoe) and an accompanying surveyor, rowed out onto Lake Ontario and came across the white sand of the local area's bluffs. Upon seeing it, Simcoe was reminded of Scarborough, England and the bluffs there that defined and constituted the community's central geographic feature. Already named Glasgow, the area that "appeared so well" was renamed Scarborough by John Graves Simcoe, a name that remains to this day as the official toponym of Toronto's easternmost borough (The Scarborough Historical Society, n.d.). I begin with this example of common toponymic renaming for two reasons. First, the ease with which a place is renamed is fundamental to the settler geographic effort and desire to remake space, which functions to deny the long history of Indigenous naming practices of the area, in favour of colonial transplants and/or inventions (Razack, 2011; Veracini, 2014). In the case of Scarborough, what gets obscured are the various names for the area including Ganatsekwyagon (Onondowahgah/Seneca) to make way for the colonial fantasy of planting European toponyms as markers of dominion (Centre for Community Mapping, 2015; Turner, 2015). ${ }^{1}$ Second, this consequential and rather easy remaking exemplifies the geographic dynamic of what Stanley (2009) calls the "banality of colonialism" and the pervasive reach of settler historical commemoration across space. Scarborough, for instance, is often taken up in conversation as a toponymic given and insulated from a critical engagement that can help to highlight its contingency and continued success as a product and necessity of settler politics.

This remaking of space and the banality of colonial erasures that allow for the reformation of named lands, I argue, are forgotten in the sometimes myopic focus on the abhorrent few (e.g., Macdonald and Cornwallis). The latter abhorrent group, I suggest, come to, in the landscape of public thought and opinion pieces, monopolize critical efforts and position settler dominance as an isolated event rather than endemic in contemporary Canada. In response, I suggest that social studies scholars and pedagogues would be wise to read "more broadly" across

\footnotetext{
${ }^{1}$ Interestingly, as Rayburn (1999) argues, Scarborough's original colonial toponym, Glasgow, was renamed to Scarborough because it wasn't, “'British' enough to persuade Loyalists to the British crown to settle in Upper Canada" (p. 318). Separately, it's worth noting that there doesn't appear to be a definitive "original" name for what now constitutes Scarborough and instead, Ganatsekwyagon is the name of a village that was situated at the mouth of the Rouge River (which cuts through Scarborough). Here, then, I acknowledge the tenuousness and limitedness of the original name offered. Indeed, as Celia Haig-Brown (2009) reminds us, this is further complicated by the fact that numerous Indigenous nations have occupied these lands at various times (and continue to do so).
} 
space and engage the settler geographic project of spatial dominion and erasure by looking at what critical toponymers call the "city-text" and the role of street names in (re)producing settler histories of place. $^{2}$

\section{The City-Text: Reading Settler Toponymic Reach}

My argument for a re-focusing of social studies conversations of commemoration is premised on the notion that communities are textual artifacts and that the maps which make them intelligible, "reflect the spatial identities of those whose activities, dreams, aspirations, and everyday lives take place within the frame depicted" (Eades, 2015, p. 82). In settler contexts, the officially sanctioned cartographies produce settler conceptions of place and identities that are inescapably articulated with the history of mapped space. These histories come to be normalized, support and rendered sensical through the "city-text," "a representation of the past" (Azaryahu, 1990 , p. 33) that "functions as a system of representation and an object of political identification" (Palonen, 2008, p. 220) that works through street names. Across communities, the text operates in unconventionally organized ways (Azaryahu, 2009; Ryan, Foote, \& Azaryahu, 2016), that, while shunning conventional narrative structure, ${ }^{3}$ plots particular historical moments and actors across the textual/geographic landscape. These moments and actors, almost exclusively heroic in their character (Azaryahu, 2011), are shaped by popular commitments to a political project of normalizing histories of "us." As Azaryahu (1996) suggests, "commemorative street names, which are a conventional element of the urban texture, play a special role in naturalizing a prime cultural construct: an hegemonic version of history" (p. 319).

Hegemonic versions of history, we must remember, are often predicated on the perpetual re-centring of European exploits as the essential measure of "progress" in Canada. In social studies scholarship, there are concerted efforts to question the grand narrative of Canadian history which functions to produce, "a 'we' [that] is created through which 'our' stories become one and the same as the past and through which 'we' interpret 'our' contemporary realities" (den Heyer \& Abbott, 2011, pp. 610-611). This production of a (re)fixed "us" that appears stable in the historical imaginary and normalized/created in schools, is spatially supported by the perpetuation of an "us" that appears at every literal street corner.

\section{Banal Place-Naming and Settler Geography: The Example of Toronto}

In the place known as Toronto, the textual dimensions of "spatial-historical" organization - the city-text - is one through which European commemorations overwhelm the city's central cartographic spaces while Indigenous toponyms are relegated to locations that are physically marginalized to the spatial peripheries and/or are denied the same scalar privileges afforded to European named spaces (e.g., major thoroughfares or highways) (Casagranda, 2013). For example, Appendix A illustrates the overwhelming presence of colonial toponyms in the

\footnotetext{
2 I don't suggest, by any measure, that street names are the exclusive or the qualitatively most important site of critical work against settler banality. Instead, I offer street names as an object of critique given their central place in all communities.

${ }^{3}$ Streets are by no means organized cartographically from west-east/left-right such that a coherent narrative can be discerned from the map. Instead, street names serve to plot characters and events in a seemingly scattered way that helps to further render the city-text's narrative more difficult to understand.
} 
city's downtown space including "Dufferin," "Oxford," "Ulster," "Brock" and "Queen" (including the colonial label for Indigenous people, "Indian"). "Queen" is particularly interesting in that it works elliptically, rendering the colonial and national project even more banal by further hiding settler geographic normalcy through the removal of explicit referents (i.e., which queen?) that, implicitly, reinscribe the logics of British spatial prominence in the city space (see Billig, 1995; Stanley, 2009). Simultaneously, as Casagranda (2013) reminds us and as Appendix B illustrates, while clusters of Indigenous toponyms can exist in the city-text, they are commonly pushed to the margins of the city and used for streets with smaller scale (itself marginalizing the prominence of the names in the city-text).

The dual prominence of settler naming and the marginalization of Indigenous toponyms serves to spatialize and "toponymize" what Donald (2009) has noted as the logics that separate and naturalize divisions between Indigenous peoples and Canadians. In a community such as Toronto (albeit by no measure exclusive to it), what makes this "toponymizing" of historical narration hard to discern and engage with is its simultaneously pervasive reach and the emptying of meaning from toponyms. For example, in a debate last year about Jarvis Street downtown Toronto, one brought into consciousness by justified concerns on the part of Black Lives Matters that the street commemorates the Jarvis family-William Jarvis was a slaveholder and his son, Samuel, was Chief Superintendent of Indian Affairs - many of the responses to the protest were characterized by indifference and/or suggestions that the commemorative function of the street name was inconsequential because "it is just a street name" (Errett, 2016). Some commenters asked, for example, "why does this matter?" and "who cares" with others ignoring the legacies heralded into (perpetual) existence by suggesting that we "deal with the here and now" and that, "that was then, this is now.... leave it alone, no one cares, it's just a name" (n. p.). Reflected here is the power of toponyms to reimagine patterning of dominance in ways that are rendered inert and in a place such as Toronto, this has the consequence of re-normalizing the spatialization of the centre/periphery as "just is." Or, as Azarayhu (1996) reminds us with respect to street names, "their apparent dailiness and apparent insignificance as well as their recurrent and unreflected use in various contexts, both ordinary and extraordinary, renders the past they represent tangible and intimately familiar" (p. 321), and in settler-contexts, this reproduces comforts with settler (re-)formations of named space and the reinscription of settler history as History.

\section{Conclusion}

Critical toponymers Reuben Rose-Redwood and Derek Alderman (2011) argue that, "critical place-name scholars have typically focused on the most dramatic political conflicts over place naming while ignoring those namescapes that present themselves as apparently beyond contestation due to their utter banality" (p. 3). I fear that the same concerns here may appear in social studies conversations if we fall into the attractive trap that is a preoccupation with the "dramatic" to the exclusion of the banal. Critiques of Macdonald and Cornwallis as unworthy of public commemoration are warranted and necessary, particularly as each was instrumental in cementing settler-colonial projects of dominion and erasure of Indigenous populations, but each figure is but one point (or multiple) in the web of articulations that comprise the city-texts of Canada. Focusing on the dramatic blinds us to the mundanity of settler geography, one equally pernicious in normalizing the idea that the settler project and its actors serve as the exclusive reservoir of historical commemorative meaning. What is required as a response is a critique of 
the histories that live through the streets, parks and "extremely bold" sites for a summer residence that define our communities.

\section{References}

Alderman, D. H. (2003). Street names and the scaling of memory: The politics of commemorating Martin Luther King, Jr within the African American community. Area, 35(2), 163-173.

Azaryahu, M. (1990). Renaming the past: Changes in "city text" in Germany and Austria, 19451947. History and Memory, 2(2), 32-53.

Azaryahu, M. (1996). The power of commemorative street names. Environment and Planning D: Society and Space, 14(3), 311-330.

Azaryahu, M. (2009). Naming the Past: The Significance of Commemorative Street Names. In L. D. Berg \& J. Vuolteenaho (Eds.), Critical Toponymies: The Contested Politics of Naming (pp. 53-70). Burlington, VT: Ashgate.

Azaryahu, M. (2011). The critical turn and beyond: The case of commemorative street naming. ACME: An International E-Journal for Critical Geographies, 10(1), 28-33.

Billig, M. (1995). Banal Nationalism. Thousand Oaks, CA: Sage Publications, Inc.

Casagranda, M. (2013). From Empire Avenue to Hiawatha Road: (Post)colonial Naming Practices in the Toronto Street Index. Proceedings of the International Conference on Onomastics "Name and Naming” 2, 291-302. Retrieved from http://onomasticafelecan.ro/iconn2/proceedings/3 06 Casagranda Mirko ICONN 2.pdf

Centre for Community Mapping. (2015). First Story Toronto (Version 1.1.2) [Mobile Application Software]. Retrieved from http://itunes.apple.com.

den Heyer, K., \& Abbott, L. (2011). Reverberating echoes: Challenging teacher candidates to tell and learn from entwined narrations of Canadian history. Curriculum Inquiry, 41(5), 610 635.

Donald, D. (2009). Forts, curriculum, and Indigenous Métissage: Imagining decolonization of Aboriginal-Canadian relations in educational contexts. First Nations Perspectives: The Journal of the Manitoba First Nations Education Resource Centre, 2(1), 1-24.

Eades, G. L. (2015). Maps and memes: Redrawing culture, place, and identity in Indigenous communities. Kingston, Canada: McGill-Queen's University Press.

Errett, J. (2016, May 7). Was Jarvis Street named after a city-builder, or a slave-owner? Prepare for a debate. CBC News. Retrieved from http://www.cbc.ca/news/canada/toronto/jarvisstreet-slavery-1.3564667

Haig-Brown, C. (2009). Decolonizing diaspora: Whose traditional land are we on? Cultural and Pedagogical Inquiry, 1(1), 4-21.

Palonen, E. (2008). The city-text in post-communist Budapest: Street names, memorials, and the politics of commemoration. GeoJournal, 73(3), 219-230.

Rayburn, A. (1999). The transfer of Scottish placenames to Canada. Names: A Journal of Onomastics, 47(3), 313-323.

Razack, S. (2011). Colonization: The good, the bad, and the ugly. In A. Baldwin, L. Cameron, \& A. Kobayashi (Eds.), Rethinking the great white north: Race, nature, and the historical geographies of whiteness in Canada (pp. 264-271). Vancouver, Canada: UBC Press.

Robertson, J. R. (1911). The diary of Mrs. John Graves Simcoe: Wife of the first lieutenant governor of the province of Upper Canada, 1792-6. Toronto, Canada: William Briggs. 
Rose-Redwood, R., \& Alderman, D. (2011). Critical interventions in political toponymy. ACME: An International E-Journal for Critical Geographies, 10(1), 1-6.

Ryan, M.-L., Foote, K., \& Azaryahu, M. (2016). Narrating space/spatializing narrative: Where narrative theory and geography meet. Columbus, $\mathrm{OH}$ : The Ohio State University Press.

Stanley, T. J. (2009). The Banality of colonialism: Encountering artifacts of genocide and white supremacy in Vancouver today. In S. R. Steinberg (Ed.), Diversity and multiculturalism: A reader (pp. 143-159). New York, NY: Peter Lang.

The Scarborough Historical Society. (n.d.). The Naming of Scarborough. Retrieved from http://scarboroughhistorical.ca/local-history/naming-of-scarborough/

Turner, G. (2015). The Toronto carrying place: Rediscovering Toronto's most ancient trail. Toronto, Canada: Dundurn.

Veracini, L. (2014). Understanding colonialism and settler colonialism as distinct formations. Interventions, 16(5), 615-633.

Wise, L., \& Gould, A. (2011). Toronto Street Names: An Illustrated Guide to their Origins (Revised and Expanded ed.). Richmond Hill, ON: Firefly Books Ltd.

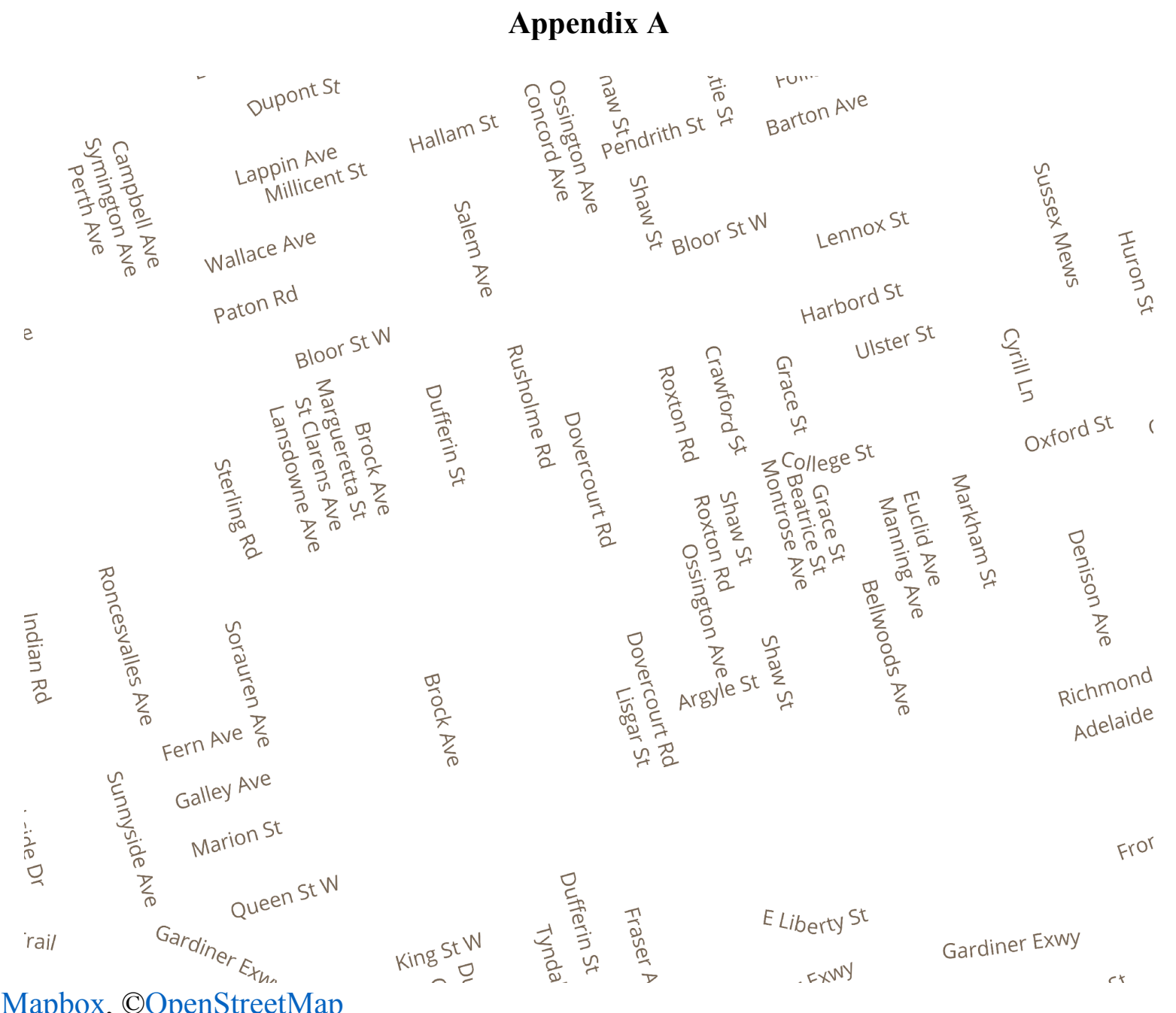




\section{Appendix B}

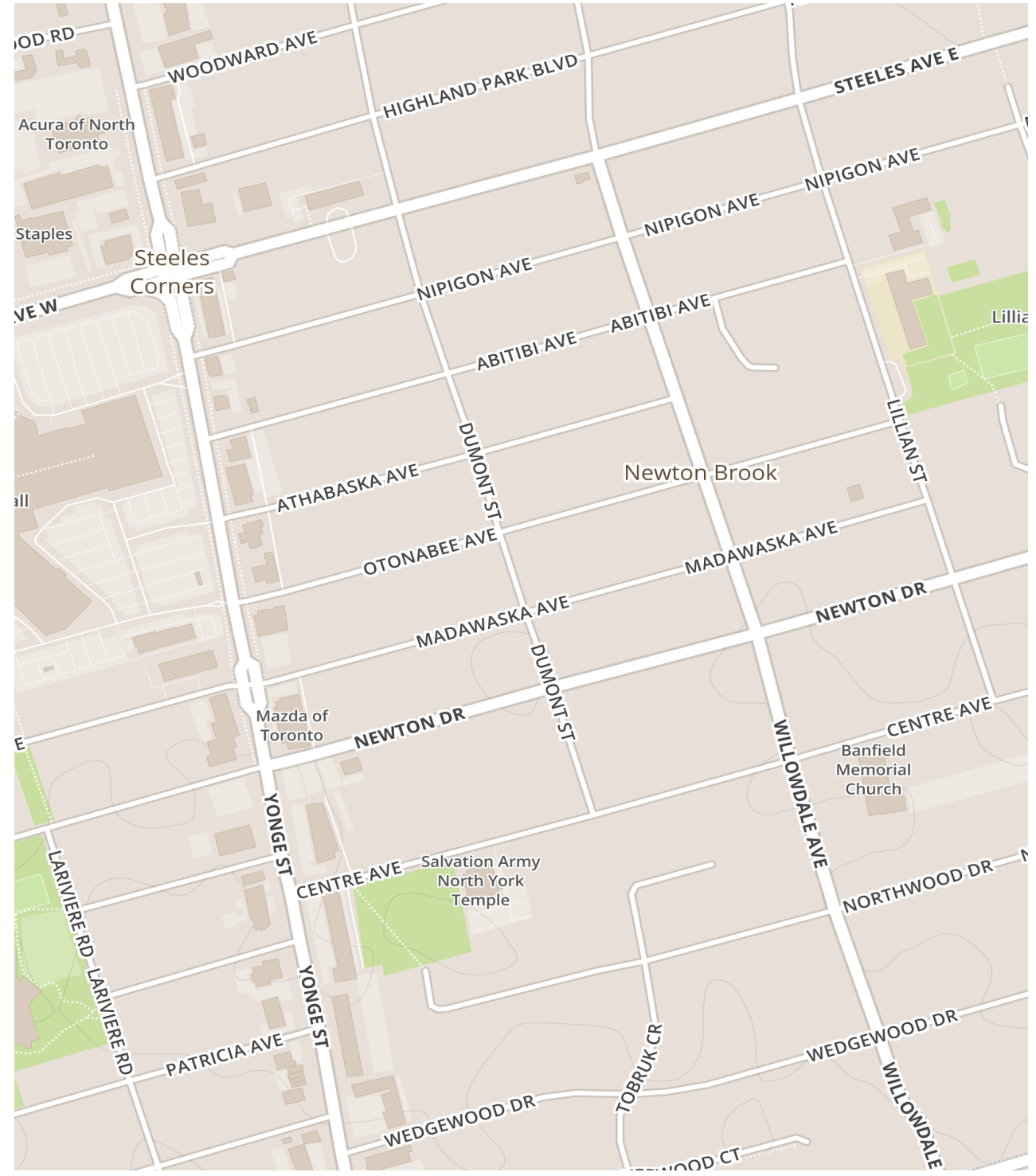

\section{(C) Mapbox, (c) OpenStreetMap}

Here, there is a concentration of Indigenous toponyms concentrated at the corner of Yonge Street and Steeles Avenue (West and East). Important to note here is that Steeles Avenue serves as the official political boundary for Toronto's north end. In this respect, the cluster of Indigenous toponyms-Nipigon, Abitibi, Athabaska, Otonabee and Madawaska - is concentrated at the literal margins of the city's politically defined space. Further, there is a particular scalar advantage afforded to "Yonge" and "Steeles" (named for English people (Wise \& Gould, 2011)) that, by virtue of their arterial nature, enjoy greater prominence in popular language of space. This is by no means inconsequential. As Alderman (2003) reminds us, "a restriction in the scale of commemoration can decrease the retrievability and accessibility of the past" (p. 165); here, the reduction in scale (size) of Indigenous toponyms and the features which they mark are indicative of a decrease in "retrievability" of Indigenous presence in the commemorative and historical landscape of the city. And while this is only one example, it serves to draw attention to how space can serve to, in quite literal ways, marginalize histories that don't fit with the banality of European commemorative privilege. 